\title{
Beliefs and purchasing practices of Cape Town consumers regarding organically produced food
}

\author{
Linda du Toit \& Sharon Crafford
}

\section{OPSOMMING}

Daar was die afgelope dekade ' $n$ beduidende toename in die vraag na organies geproduseerde voedsel. Tog is die markaandeel wêreldwyd steeds minder as $3 \%$ van voedselkleinhandelwaarde. Hierdie navorsing fokus op verbruikersoortuiginge van organies geproduseerde voedsel en organiese boerdery, sowel as die aankooppraktyke van sodanige produkte. ' $n$ Vraelys is deur kliënte van vier Kaapstadse takke van ' $n$ kleinhandel-kettinggroep voltooi. Op grond van die inligting ingewin, is aanbevelings aan ' $n$ kleinhandel-kettingroep oor die bemarking van organies geproduseerde voedsel gedoen. Huidige literatuur wys daarop dat verbruikers spesifieke oortuiginge rakende die intrinsieke kenmerke (bv voedingswaarde, gifstofreste) van organies geproduseerde voedsel en aangaande organiese boerdery (bv omgewingsbeskerming, dierewelsyn) het. Die resultate van hierdie studie toon ooreenstemming met internasionale bevindinge. Ten opsigte van aankooppraktyke is vasgestel dat persone ouer as 36 wat Engels as huistaal en ' $n$ hoër vlak van opvoeding het, aangedui het dat hulle meer dikwels hierdie produkte koop. Frekwensie van aankope word verder beïnvloed deur prys en beskikbaarheid van produkte. Aanbevelings aan die kleinhandelgroep sluit onder meer in dat die pryspremie tussen $10 \%$ en $20 \%$ moet bly en dat organies geproduseerde produkte duidelik onderskeibaar en aanloklik aangebied moet word. Oortuigende bemarkingstategieë is nodig indien die kleinhandelfirma ' $n$ groter markaandeel ten opsigte van organies geproduseerde voedsel wil bereik.

\section{- Ms LD du Toit}

- Mrs S Crafford

Department of Food and Agricultural Sciences, Faculty of Applied Sciences, Cape Technikon

\section{INTRODUCTION}

During the past decade the demand for organically produced products has expanded rapidly with the European Union, the United States and Japan as the main markets (De Haen, 1999; Benbrook, 1998). Despite a significant growth over the period 1995 - 2000 (Jones et al, 2001), the market share was still less than $3 \%$ of retail food sales throughout the world in 2000 (Thompson, 2000).

A demand for organically produced food is emerging in some developing countries (De Haen, 1999). In South Africa retail companies are responding to the consumer demand for organically produced food (Hartmann, 2001) and most major retail stores carry a limited selection of these products.

In order to promote organically produced products, a cohesive marketing strategy is needed which depends on a better and fuller understanding of food consumers (Hutchins \& Greenhalgh, 1997). While research on consumer perceptions, beliefs, attitudes and purchasing practices of organically produced food has been done in the United States of America (Williams \& Hammitt, 2000; Jolly et al, 1989; Huang, 1996), Great Britain (Wright, 1997), The Netherlands (Hack, 1993), Germany (Von Alvensleben, 1998) and New Zealand (Saunders, 1999), research related to consumer beliefs and purchasing practices of organically produced food products in South Africa is still limited.

The goal of this study was to determine the beliefs regarding organically produced food, organic farming and food purchasing practices of Cape Town consumers. Based on the insights gained, recommendations were made to the retail company regarding marketing strategies for organically produced food. As these products increase in range and availability, further studies could investigate the actual organically produced food-purchasing behaviour of the South African consumer.

\section{LITERATURE REVIEW \\ Conceptual framework}

The Engel-Blackwell-Miniard model of consumer behaviour (Engel et al, 1990:482) was chosen as a framework for the research. This model (figure 1) has a central focus on the five basic stages of consumer decision-making. The problem recognition stage is followed by the search, evaluation of alternatives, purchase and outcomes stages. During the alternative 


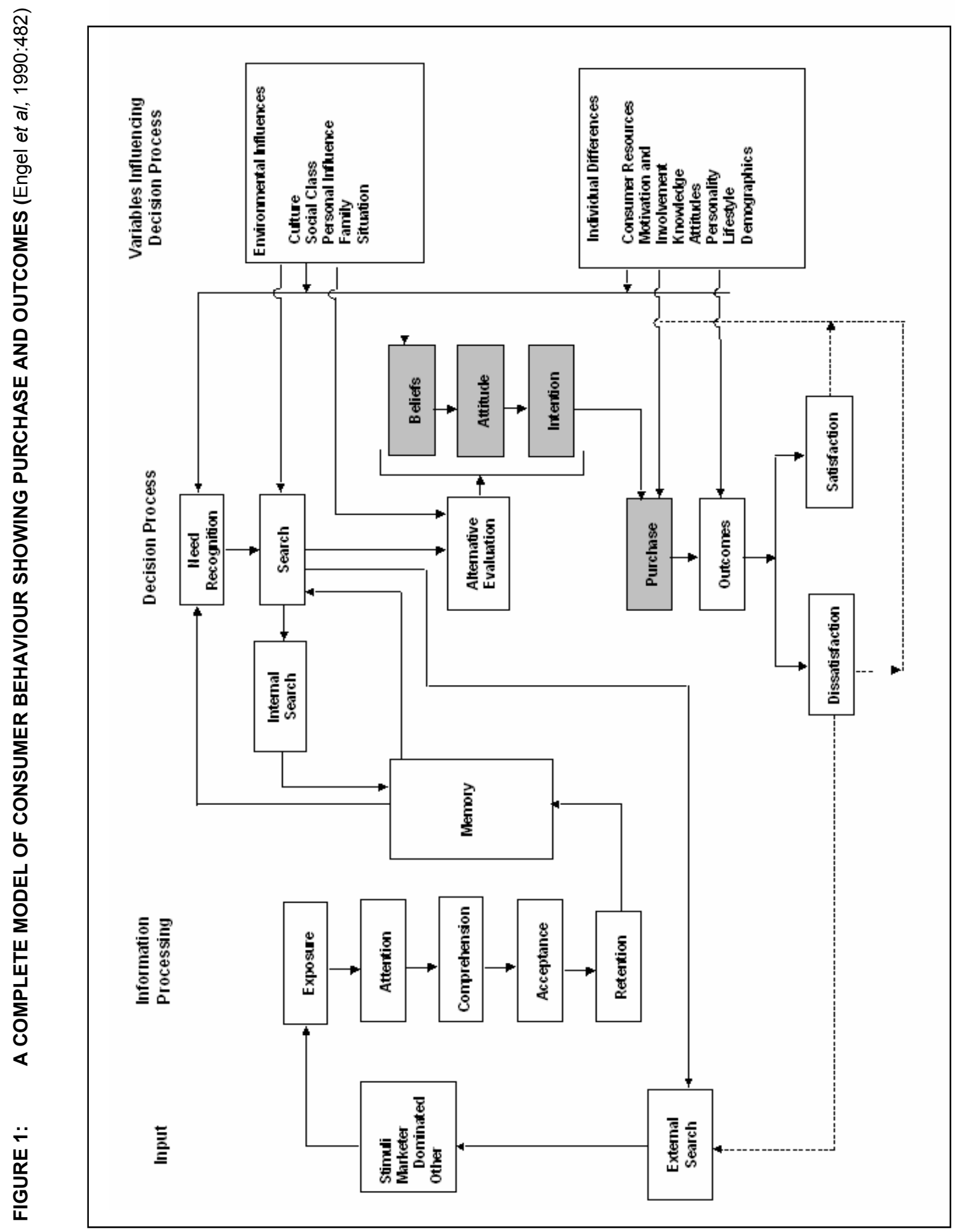


evaluation stage, beliefs may lead to the formation of attitudes, which in turn may result in a purchase intention (Schiffman \& Kanuk, 1994:648). Each of the five stages in the process is affected by environmental influences as well as individual differences such as knowledge and attitudes.

\section{Key concepts}

Beliefs are seen as synonymous with knowledge (Peter \& Olson, 1994:460) and refer to the consumers interpretation and assessment of a retail outlet, product or brand (Schiffman \& Kanuk, 1994:409). Consumer beliefs about products are often concerned with the attributes or functional consequences of the products (Peter \& Olson, 1994:460; Sheth et al, 1999:390).

Consumers acquire numerous beliefs about products through their various experiences, but due to the limited capacity of active memory only a few of these beliefs can be activated and consciously considered at a time. These beliefs are described as salient beliefs (Peter \& Olson, 1990:141) and provide the basis for the formation of an attitude towards a specific object (Fishbein \& Ajzen, 1975:131). An attitude is defined as a learned predisposition to behave in a consistently favourable or unfavourable way to a given object (Schiffman \& Kanuk, 1994:240). Attitudes are usually measured by assessing a person's beliefs (Fishbein \& Ajzen, 1975:131).

Beliefs may be acquired by direct experience with the object and/or various other sources of information. Consumers may believe that a specific object possesses certain attributes, although it may not be scientifically proven (Du Plessis, 1994:107). The focus of this study was not on whether food products produced by organic farming methods were inherently different from the same products produced by conventional methods, but whether the consumers surveyed believed that there was a difference.

Attitudes do not lead directly to specific behavioural patterns, but are seen as a pre-disposition or motivational quality that propels a person towards or repels a person from a particular behaviour (Schiffman \& Kanuk, 1994:240). Attitudes influence the way a person is likely to respond to a specific situation and are used by marketers to predict behaviour (Schiffman \& Kanuk, 1994: 389). Marketers also use the data of consumer attitude surveys to position a particular brand against competitive brands (Schiffman \& Kanuk, 1994:241).

In this study the beliefs of consumers regarding organic foods and organic farming were used as a basis for the recommendations made to the retailer on marketing strategies for organically produced food.

For the purpose of this study purchasing practices included the frequency of purchasing, the location where purchasing took place, the willingness of the consumer to pay within a specific price range and the choice of product.
Organically produced food is the result of organic farming production systems that are described by the USA Department of Agriculture (1981) as follows: Organic farming is a production system which avoids or largely excludes the use of synthetically compounded fertilisers, pesticides, growth regulators and livestock feed additives to the maximum extent feasible. Organic farming systems rely on crop rotation, crop residues, off-farm organic wastes, mechanical cultivation, mineral bearing rocks and aspects of biological pest control to maintain soil productivity and tilth to supply plant nutrients and to control insects, weeds and other pests (Beharrell \& MacFie, 1991:25).

Organic food is the term commonly used by consumers and the retail industry, and was used by the researchers in the collection of data.

\section{Consumer beliefs regarding organically produced food and organic farming}

The food habits and dietary patterns of consumers world-wide are changing (Huang, 1996; Hay, 1989) with more people focusing on health and well-being (Davies et al, 1995; Wier \& Calverley, 2002). Food has become more integrated with health aspects and consumers are becoming more informed about nutrition (Huang, 1996; Wiley, 1996).

In the United Kingdom there appears to be a widespread belief that organically produced crops and animal products have a higher nutritional value (Williams, 2002). This corresponds with the results of a study done in Washington State where respondents indicated that organically grown food had more health benefits and a higher nutritional value than conventionally grown food (Wilkens \& Hillers, 1994). In surveys conducted by Magnusson et al (2001) in Sweden, Hutchins and Greenhalgh (1997) in the UK and Tregear et al (1994) in Ireland, organically produced foods were believed to be healthier than conventionally produced alternatives.

Food safety concerns have increased significantly over the past decade (Williams \& Hammitt, 2000). Consumers are becoming increasingly aware of the possible health hazards associated with processed food (Ehlers \& Fox, 1982) and food produced by intensive farming methods (Williams, 2002). Consumers also ask more questions and express greater concerns about food quality and safety than in past decades (Jones et al, 2001; Sloan 1999; Huang 1996).

In the USA and Great Britain surveys indicate that consumers display a high level of concern over pesticide residues on food products (Jolly et al, 1989; Lane \& Bruhn, 1992; Benbrook, 1998; Davies et al, 1995). In the study conducted by Jolly et al (1989) in California, $46 \%$ of the respondents believed that organically produced food did not contain any pesticide residues, and in the 1997 Hartmann report $78 \%$ of respondents believed that "organically grown" meant that no pesticides were used to produce the food (Benbrook, 1998). 
Regarding the sensory characteristics of organically produced food, consumers believed that these food products were less appealing (Hay, 1988) but that they tasted better than conventionally grown products (Tregear et al, 1994; Davies et al, 1995; Ekelund, 1989).

Consumers who care about the environment have a high regard for organic farming (De Haen, 1999). In surveys in the United States respondents rated environmental concerns as important as health reasons for consuming organically produced food (Jolly et al, 1989 ) and $79 \%$ of respondents in a study by Swanson and Lewis (1993) believed that organic farming was safer for the environment. De Haen (1999) notes that some consumers associate environmental and ethical values with organic farming and believe that organic farming protects the environment and that it leads to a more sustainable use of natural resources. The Consumers Association found in a survey conducted in the United Kingdom that $75 \%$ of the consumers agreed with the statement that organically produced food was kinder to the environment. Respondents are turning to organically produced food because they are worried about the intensive rearing of animals (70\%) and to support local farmers (40\%) (Wright, 1997).

Consumers are thus becoming more concerned about the food they eat, not only in terms of intrinsic factors (eg chemical residues, environmental contamination and nutritional content), but also with regard to broader environmental issues such as the impact on the environment and the welfare of animals (Beharrell \& MacFie, 1991; Wiley, 1996).

In studies investigating the reasons why consumers buy organically produced food, the major motives relate to the beliefs of consumers. Roddy et al (1996:41) summarized the findings of consumer surveys on organically produced foods in the USA, Canada, UK, Germany, Denmark and Sweden and came to the following conclusions: organically produced food was purchased because it was healthier and more nutritious than conventionally grown food, it contained no harmful chemical residues, it tasted better than conventional food, and organic farming is kinder to the environment and showed support to local farmers.

\section{Purchasing practices}

Of importance to the retailer is where and how often consumers purchase organically grown food. Retailers would also take the price premium consumers are willing to pay and the specific food product/s that they would like to purchase into account when formulating marketing strategies. In studies conducted by Ekelund (1989) and Wilkens and Hillers (1994), a high percentage of the respondents indicated that they had a preference for organically produced food. Yet the proportion of consumers who purchase organically produced food on a regularly basis is low (Von Alvensleben, 1998; Roddy et al, 1996; Wandel \& Bugge, 1997).
According to Thompson (1998) store choice is a critical variable in explaining purchasing of organically grown food. Although during the 1990s there was a move of organically produced food products from speciality outlets into mainstream retail venues (Thompson, 2000), most organically grown food products remained available in speciality stores and markets. In a survey conducted by Hutchins and Greenhalgh (1997), all respondents indicated that they would like organically produced food to be sold in supermarkets. According to Saunders (1999) the main purchasing criteria affecting organically grown food is availability, and if consumers have to spend extra time and effort locating organically produced food, the sales volume will be affected negatively (Thompson, 2000). This in turn could have a detrimental effect on the price.

The major impediment to the continued growth in demand for organically produced food is the existing price difference (Magnusson et al, 2001). In the Netherlands Hack (1993) found that $80 \%$ of the consumers surveyed believed that organically produced food was too expensive. Wandel and Bugge (1997) came to similar conclusions in a Norwegian study. Based on the information from the polling group MORI, Wright (1997) concluded that six out of ten people would choose organically produced food if it was readily available and cost no more than conventional food. Beharrell and MacFie (1991) reported that consumption increased sharply when the price premium was below $20 \%$. Studies conducted by Huang (1996) and Ott (1990) showed that consumer resistance increased as premiums for organically produced food increased (Lohr \& Semali, 2000:206).

Studies conducted in the USA, The Netherlands, Spain, Italy, Denmark and New Zealand suggest that habitual buyers of organically produced food are willing to pay higher premiums than consumers buying less frequently (Thompson, 2000).

Thompson (2000), however, states that where studies of willingness to pay have been augmented by experimental studies, the stated willingness to pay often exceeds actual payment behaviour. Huang (1996) agrees with this statement and points out that there is no assurance that stated preferences always translates into market behaviour.

The range of organically grown food has expanded from mainly fruit and vegetables to include dairy products, meat and prepared convenience items (Thompson, 2000). In studies conducted in New Zealand (Saunders, 1999), The Netherlands (Hack, 1993) and Boston, USA (Williams \& Hammitt, 2000), it was found that the most common purchases of organically produced food were in the category of fruit and vegetables, followed by poultry and dairy products. Even though fruits and vegetables already represent a major part of the market, there is still the possibility for further growth, especially for fruit, prepared vegetables and salads (Wier \& Calverley, 2002). In the UK upscale supermarkets like Waitrose, J Sainsbury and Tesco Stores sell over 300 organically produced food 
items ranging from fresh fruit and vegetables to dairy and convenience foods, and in Austria Billa and Spar chains are promoting their own store brands of organically grown food (Thompson, 2000). The greatest potential for future growth in the European market is expected by Wier and Calverley (2002) for convenience food and frozen products, followed by sweets and snacks as well as meat products.

\section{RESEARCH DESIGN}

\section{Measuring instrument}

The survey was conducted by means of a questionnaire based on findings from a review of consumer surveys (Roddy et al, 1996; Magnusson et al, 2001). The content validity was determined by subjecting the questionnaire to consumer behaviour and food subject specialists at the Cape Technikon.

Beliefs were measured using a five point scale of "strongly agree" to "strongly disagree" for a number of statements (see Tables 1 and 2). Respondents were presented with 18 statements relating to organically produced foods and 11 statements on farming practices used in the production of organically produced foods. Purchasing frequency, locality, WTP (willing to pay) and a yes/no product-choice question were also included. Lastly, biographical questions were included such as gender, age, home language, educational level, income and the identification of the main food purchaser in the household.

No definition of organically produced food was given in the questionnaire since the existing beliefs of the consumers regarding the term "organic" was being explored.

\section{Field workers}

Four volunteer students from the Food and Consumer Sciences programme at the Cape Technikon were used to distribute the questionnaires in the four retail stores identified by the retail company who commissioned the study. These outlets were identified as being the most representative of the consumer profile under investigation for market research purposes.

The survey took place on two consecutive Saturdays (11 and 18 August 2001) between the hours of 11:00 and 13:00, usually the busiest time. The branch managers of the four outlets recommended the days and times for the surveys to ensure that the consumers being targeted would be included.

\section{Respondents}

The field workers approached food consumers close to the entrance of the fresh organically produced food section in the four retail outlets to participate voluntarily in the survey.

A total of 480 consumers, who were acquainted with the concept of organically produced foods, were asked to complete a questionnaire at home and post their response back in the self-addressed envelope. All returned questionnaires were included in a lucky draw for a hamper of organically produced food, which was won by one participant.

A total of $75(15,4 \%)$ questionnaires were returned for data analysis. Time constraints and the preliminary nature of the research resulted in a decision not to increase the low response by handing out more questionnaires. The understanding was that the questionnaire would be re-used by the retail company nationally at a later stage.

The biographical information of the respondents is summarised in Table 1.

\section{Data analysis}

The SPSS for Windows program was used for the statistical analysis of the data. The chi-square test $\left(c^{2}\right)$ was chosen to test dependency between the variables and the level of significance used was $p=0,05$ or 0.01 .

Variables of section A (perceptions on organic foods) were cross-tabulated with variables of section B (perceptions on organic farming), section $\mathrm{C}$ (purchasing behaviour) and section $D$ (biographical factors) to determine significant differences.

\section{RESULTS AND DISCUSSION}

\section{Consumer beliefs regarding organically produced foods}

Table 2 shows that most consumers had positive beliefs regarding organically produced food as they generally regarded them to be healthier, more nutritious, more flavourful and tastier than conventional food. The majority of respondents believed that organically produced food contained no artificial additives and was less contaminated by pesticide residues than conventional food. This corresponds with the results of studies conducted by Williams (2002), Williams and Hammit (2000) and Jolly et al (1989). Organically produced food was believed to be as attractive as conventional foods, but most consumers were undecided on the shelf-life aspect. An oftencited obstacle to the purchase of organically produced food is availability (Saunders, 1999; Hutchins \& Greenhalgh, 1997) and most respondents indicated that organically produced food was hard to find when shopping. In retail outlets labelling distinguish organically produced food products from conventional produce (Jones et al, 2001; Wier \& Calverley, 2002) and most consumers agreed that organically produced food products should be certified.

\section{Consumer beliefs regarding organic farming}

As indicated in Table 3, organic farming was com- 
TABLE 1: $\quad$ BIOGRAPHICAL INFORMATION ON RESPONDENTS ( $\mathbf{N}=\mathbf{7 5}$ )

\begin{tabular}{|c|c|c|c|c|c|c|c|c|c|}
\hline \multicolumn{2}{|c|}{ Gender } & \multicolumn{2}{|l|}{ Age } & \multicolumn{2}{|c|}{ Home language } & \multicolumn{2}{|c|}{$\begin{array}{c}\text { Highest educational } \\
\text { level }\end{array}$} & \multicolumn{2}{|c|}{$\begin{array}{l}\text { Household income } \\
\text { per month }\end{array}$} \\
\hline Female & $89,4 \%$ & $36-45$ & $28,0 \%$ & English & $68,1 \%$ & Secondary & $68,0 \%$ & $\begin{array}{l}\text { R10 } 000 \text { or } \\
\text { more }\end{array}$ & $49,3 \%$ \\
\hline Male & $9,3 \%$ & $21-35$ & $25,3 \%$ & Afrikaans & $24,0 \%$ & Tertiary & $22,7 \%$ & $\begin{array}{l}\text { R5 } 000- \\
\text { R9 } 999\end{array}$ & $33,3 \%$ \\
\hline & & $46-55$ & $18,7 \%$ & Other & $2,7 \%$ & Primary & $2 \%$ & $\begin{array}{l}\text { R4 } 999 \text { or } \\
\text { less }\end{array}$ & $10,7 \%$ \\
\hline & & $56-65$ & $21,3 \%$ & Xhosa & $1,3 \%$ & $\begin{array}{l}\text { Non- } \\
\text { formal }\end{array}$ & $1,3 \%$ & & \\
\hline $\begin{array}{l}\text { No re- } \\
\text { sponse }\end{array}$ & $1,3 \%$ & $\begin{array}{l}\text { No re- } \\
\text { sponse }\end{array}$ & $1,3 \%$ & $\begin{array}{l}\text { No re- } \\
\text { sponse }\end{array}$ & $4 \%$ & $\begin{array}{l}\text { No re- } \\
\text { sponse }\end{array}$ & $5,3 \%$ & $\begin{array}{l}\text { No re- } \\
\text { sponse }\end{array}$ & $6,7 \%$ \\
\hline
\end{tabular}

TABLE 2: $\quad$ RESPONSE REGARDING ORGANICALLY GROWN FOOD (N = 75)

\begin{tabular}{|l|c|c|c|}
\hline Organically grown foods: & $\begin{array}{c}\text { Agree } \\
\%\end{array}$ & $\begin{array}{c}\text { Undecided } \\
\%\end{array}$ & $\begin{array}{c}\text { Disagree } \\
\%\end{array}$ \\
\hline are healthier & 85,4 & 13,3 & 1,3 \\
\hline have similar health benefits & 38,7 & 20,0 & 41,3 \\
\hline contain the same amount of nutrients & 44,0 & 20,0 & 36,0 \\
\hline contain more nutrients & 70,7 & 24,0 & 5,3 \\
\hline contain less pesticide residues & 88,0 & 10,7 & 1,3 \\
\hline may have pesticide residues & 18,7 & 24,0 & 57,3 \\
\hline contain no artificial colourants, flavourants and preservatives & 88,0 & 8,0 & 4,0 \\
\hline have the same amount of synthetic additives & 2,7 & 46,7 & 32,0 \\
\hline have more flavour & 66,7 & 26,7 & 6,7 \\
\hline are not as tasty & 4,0 & 14,7 & 81,3 \\
\hline have more blemishes & 44,0 & 25,3 & 30,7 \\
\hline are as attractive & 69,3 & 10,7 & 20,0 \\
\hline deteriorate quickly & 29,3 & 40,0 & 30,6 \\
\hline stay fresh for longer & 18,7 & 52,0 & 29,3 \\
\hline are always available & 20,0 & 9,3 & 70,7 \\
\hline are hard to find when shopping & 74,7 & 10,7 & 14,7 \\
\hline need no additional label information & 25,3 & 13,3 & 61,4 \\
\hline must be certified & 76,0 & 20,0 & 4,0 \\
\hline
\end{tabular}

TABLE 3: $\quad$ RESPONSE REGARDING ORGANIC FARMING (N = 75)

\begin{tabular}{|l|c|c|c|}
\hline Organic farming: & $\begin{array}{c}\text { Agree } \\
\%\end{array}$ & $\begin{array}{c}\text { Undecided } \\
\%\end{array}$ & $\begin{array}{c}\text { Disagree } \\
\%\end{array}$ \\
\hline protects the environment & 93,3 & 5,3 & 1,3 \\
\hline exploits natural resources & 16,0 & 13,3 & 70,6 \\
\hline uses some artificial fertilizers and pesticides & 14,7 & 32,0 & 53,4 \\
\hline uses natural fertilizers and pesticides & 74,5 & 14,7 & 10,6 \\
\hline produces only small amounts of products & 49,3 & 30,7 & 20,0 \\
\hline can produce sufficient quantities to satisfy the national demand & 38,6 & 41,3 & 20,0 \\
\hline ignores animal welfare & 1,3 & 18,7 & 80,0 \\
\hline treats animals humanely & 77,4 & 21,3 & 1,3 \\
\hline is suited to small scale farming & 66,4 & 13,3 & 20,0 \\
\hline needs a large input of capital & 25,3 & 42,7 & 32,0 \\
\hline creates more jobs as it is labour intensive & 56,0 & 36,0 & 8,0 \\
\hline
\end{tabular}


TABLE 4: $\quad$ PURCHASING PRACTICES ( $\mathrm{N}=75$ )

\begin{tabular}{|c|c|c|c|c|c|}
\hline \multicolumn{2}{|c|}{ Frequency of purchase } & \multicolumn{2}{|c|}{ Purchase locality } & \multicolumn{2}{|c|}{$\begin{array}{l}\text { Price premium } \\
\text { (WTP) }\end{array}$} \\
\hline Often & $32,0 \%$ & Woolworths & $48,0 \%$ & $0 \%$ & $26,7 \%$ \\
\hline Sometimes & $33,3 \%$ & Other retailer & $21,3 \%$ & $10 \%$ & $48,0 \%$ \\
\hline Seldom & $28,0 \%$ & Farm stall or market & $30,7 \%$ & $20 \%$ & $16,0 \%$ \\
\hline Never & $5,3 \%$ & & & $30 \%$ or more & $5,3 \%$ \\
\hline No response & $1,3 \%$ & & & No response & $4,0 \%$ \\
\hline \multicolumn{6}{|c|}{ Product preference } \\
\hline Meat and poultry & $70,7 \%$ & Canned and bottled goods & $53,3 \%$ & Wine & $40 \%$ \\
\hline Fruit and vegetables & $92,0 \%$ & Ready meals & $53,3 \%$ & & \\
\hline Dairy products & $74,7 \%$ & Baby foods & $44,0 \%$ & & \\
\hline Grains and cereals & $73,3 \%$ & Snacks and sweets & $49,3 \%$ & & \\
\hline Pulses & $57,3 \%$ & Beverages & $53,3 \%$ & & \\
\hline
\end{tabular}

monly believed to be a small-scale environmentfriendly option where natural fertilizers and pesticides were used for the production of organically produced food products. Respondents also had positive beliefs regarding the treatment of animals and job creation. The results correspond with the results of studies conducted by Jolly et al (1989), Swanson and Lewis (1993) and Williams and Hammitt (2000). Respondents were mostly undecided on the volume of food products produced by organic farming as well as the input costs.

\section{Biographical factors related to purchasing of or- ganically produced food}

A review of the literature indicates that the type of consumer likely to be a regular purchaser of organically produced food vary considerably and do not always fall into well-defined categories. The main reasons for buying organically produced food also vary according to consumer type.

Gender Although Thompson (2000) suggested that gender was a poor predictor of the likelihood of consumers purchasing organically produced food, various other studies proved the opposite. Surveys done in Sweden (Magnusson et al, 2001), Norway (Wandel \& Bugge, 1997) and Ireland (Davies et al, 1995) show that women demonstrate a more positive attitude towards organically produced food than do men, and that it is primarily females that buy these products. Owing to the imbalance in the number of males to females (see Table 1) in the survey, it could not be determined whether there was a gender relationship to any of the other variables.

Age More than half $(52 \%)$ of the respondents were between the ages 21 to 45 . Various consumer studies in the USA concluded that the age group 18 to 29 was more concerned with environmental issues, while the age group 40 to 49 was more concerned with health issues (Thompson, 2000). This information corresponds with the results of consumer studies done in Norway (Wandel \& Bugge, 1997) and Germany (Von Alvensleben, 1997) where the younger age groups based their organically produced food purchasing behaviour on the considerations for the environment and animal welfare, whereas consideration for own health was the prominent reason given by the older age groups.

Respondents in the different age groups responded differently to the statement that organically produced food contained more nutrients. The difference was significant $(p=0.05)$.

In the age group 19 to 35 the majority of respondents $(79,0 \%)$ agreed that organically produced food contained more nutrients while 71,4 percent between the ages 36 to 45 years and 56 percent between the ages 56 to 65 agreed with this statement. Increase in age thus tends to decrease the belief of respondents regarding this statement.

In contrast it was found that there was a relationship between the age of the respondents and purchasing frequency. Fifty seven percent of respondents between the ages of 21 and 35 years bought organically produced food often or sometimes, whereas $71,5 \%$ in the age group 36 to 45 and $71,4 \%$ in the age group 46 to 55 bought organically produced food often or sometimes. In the age group 66 years and older, 75,0\% indicated that they bought organically produced food often or sometimes.

Home language Home language is often included as a variable in South African studies as it traditionally refers to cultural differences, which could indicate differences in eating habits. In this study it was found that $70,6 \%$ of the English-speaking respondents bought organically produced food often or sometimes compared to the $55,6 \%$ of the Afrikaans-speaking respondents.

Educational level Most of the respondents have secondary qualifications $(68 \%)$, while $22,7 \%$ have 
tertiary qualifications. Swanson and Lewis (1993) and Hay (1989) found that consumers with higher educational levels had a higher likelihood of purchasing organically produced food. However, some studies found no evidence of a link between educational level and the purchasing of organically produced food (Jolly, 1991). In this study, however, $76,5 \%$ of respondents with tertiary qualifications indicated that they bought organically produced food often or sometimes compared to the $60,8 \%$ of respondents with secondary qualifications. The conclusion can be made in this study that higher qualifications increase the likelihood of purchasing organically produced food.

Income Almost half of the respondents (49,3\%) indicated that they had a household income of R10 000 or more per month, 33,3\% had an income between R5 000 and R9 999 per month and the remainder of the respondents indicated their income was less than R4 999 per month. In previous reports Lohr and Semali (2000:205) as well as Thompson (2000) concluded that the income-purchase relationship was not a simple positive correlation as both low and highincome groups purchase organically produced food while middle income consumers were less likely to do so. According to Davies et al (1995) the primary factor in organically produced food purchase is the (largely female) consumers' level of personal disposable income. No relationship could be found between income and any of the other variables.

Main purchaser Most of the respondents (84,0\%) were the main food purchasers in the household.

\section{Purchasing practices}

Frequency of purchase As seen in Table 4, most of the respondents $(65 \%)$ indicated that they bought organically produced food often or sometimes. In cross-tabulation of frequency of purchase with the statement that organically produced foods are healthier, $79,2 \%$ of respondents who purchased organically produced food often agreed with the statement while $19,0 \%$ of those respondents who indicated that they purchased organically produced foods sometimes held the same view.

The majority of respondents $(87,5 \%)$ who purchased organically produced food often indicated that organically produced food was not always available, while $68 \%$ of respondents that purchased organically produced food sometimes indicated that it was always available.

Frequency of purchase was also cross-tabulated with the beliefs regarding two aspects of organic farming, namely animals and size of farms. Respondents who purchased organically produced food more often were more likely to agree with the statements that organic farm animals were treated humanely and that organic farming was suited to small-scale farming.
Place of purchase Slightly less than half of the respondents $(48,0 \%)$ buy their organically produced food from the specific retailer only. Respondents indicated that place of purchase was important and that accessibility was a priority. This agrees with the findings of studies done in both the USA (Lohr \& Semali, 2000:202) and the United Kingdom (Wright, 1997).

There is a significant difference in frequency of purchase when comparing it to place of purchase. The majority of respondents $(75,0 \%)$ who bought organically produced food products from the specific retail chain only purchased them often or sometimes, while $50,1 \%$ of respondents who shopped at the specific retail chain and/or farm markets purchased them often or sometimes, and $50,0 \%$ who also bought organically produced food from other retailers bought it often or sometimes.

Price premiums A little more than a quarter of the respondents were not prepared to pay more for organically produced food, while more than half of the respondents were prepared to pay $10 \%-20 \%$ more for organically produced food.

Hay (1989), reporting on a Canadian study, indicated that a premium of no greater than $25 \%$ was generally the most consumers were willing to pay. In summarizing the results from various studies, Magnusson et al (2001) stated that consumers seemed willing to pay about 5\%-10\% more for organically produced food.

When cross-tabulating the price premium respondents are willing to pay with age groups, home language and frequency of purchase, a significant difference on the $1 \%$ level was found.

In the age group 21 to 35 years $84,2 \%$ of the respondents were prepared to pay $10 \%-30 \%$ more for organically produced food. However, in the age groups 36 to 45,46 to 55 and 56 to 65 years, the majority of respondents were prepared to pay between $10 \%-20 \%$ more for organically produced food.

Organically produced food product ranges Most respondents would, depending on availability, purchase fruit and vegetables, then dairy products, grains and grain products, and finally poultry and meat. The less popular organic ranges were baby foods and wine.

The majority of respondents in all age groups would purchase fruit and vegetables if available.

When cross-tabulating the organic food ranges with biographical factors and purchasing practices, a significant difference was found on the $1 \%$ level for the organic food product ranges.

The majority of respondents who purchase organic foods often indicated that it would be fruit and vegetables $(95,8 \%)$, dairy products $(91,0 \%)$ and grains and grain products $(91,7 \%)$. 
All of the respondents who purchased organic foods sometimes or seldom indicated that it would be fruit and vegetables. Of the respondents who purchased organic foods sometimes, $76,0 \%$ indicated that they were interested in purchasing dairy products and $72,0 \%$ indicated that it would be grains and grain products.

Of the 36 respondents who indicated that they were prepared to pay $10 \%$ and more, $94,4 \%$ indicated that they would purchase fruit and vegetables.

\section{SUMMARY AND RECOMMENDATIONS}

This research has attempted to determine the beliefs and purchasing practices of consumers regarding organically produced food and organic farming in selected Cape Town branches of a retail chain. Most of the findings correspond with the results of consumer studies done in the UK, Europe, the United States and New Zealand where beliefs of organically produced food were principally related to health and environmental concerns.

The typical profile of the respondent indicating an interest in organic foods was as follows: older (more than 36 years of age), English-speaking and with a higher level of education. Findings regarding gender and income were inconclusive.

The majority of respondents believed that organically produced food contained no artificial additives, had fewer pesticide residues, contained more nutrients, were healthier and had more flavour than conventional foods.

Consumers also believe that the organically produced food bought from the specific retail chain has fewer blemishes when compared to the produce from farm stalls or markets. The significance of appearance is stressed by the findings of Weaver et al (1992), namely that cosmetic appearance is one of the critical factors that determines the level of demand. Basker (1998) concluded that the affluent consumer used cosmetic parameters when purchasing a food item for the first time, but that the purchase would only be repeated if the customer was satisfied with the eating quality. These characteristics should thus be emphasized in marketing communications.

The majority of respondents indicated that they recognized the external benefits of organic agriculture and believed that organic farming protected the environment, treated animals humanely and was suitable for small-scale farming. Persuasive messages emphasizing these aspects as well as the empowerment of previously disadvantaged groups through organic entrepreneurial enterprises could be used in the marketing and promotion of organically produced food.

Wier and Calverley (2002) found that the main barriers to the consumption of organically produced foods were confusing labelling, too high price premiums and insufficient supply and distribution channels. In this study the majority of respondents then also noted that organically produced food was not readily available and that many products were often hard to find. The availability of these products is important to retain the organically produced food-customer base. Consumers purchasing food products at retail stores are first concerned with finding the item they plan to buy. After that the price of the item, its substitutes, the price of complements and the inherent attributes of the product, such as quality, size and freshness enter into the purchasing decision (Lane \& Bruhn, 1992).

Based on the findings, it is suggested that the price premium range of organic foods should be in the region of $10 \%-20 \%$. It was determined that the actual price, with the exception of fruit and vegetables, was often in excess of this figure. Without reductions in retail price premiums, the market share of organically produced food could remain small. Furthermore, studies by Magnusson et al (2001) and Buzby and Skees (1994) indicate that only a small proportion of consumers purchases the organically produced varieties of the chosen target foods regularly, in spite of the fact that the majority have positive beliefs regarding these products. They suggested that price and availability were the main factors that accounted for the reported discrepancy between what consumers said they would prefer and what they actually preferred.

According to Thompson (2000) reductions of retail price premiums together with augmented signage and promotion would have greater effects than price reductions alone in increasing organically produced food purchases. On the other hand, if prices remain relatively high, customers will have to be encouraged to buy organically produced food for reasons other than price. A communication offensive presenting organically produced food as a value for money alternative, even with a premium, could be adopted.

In order for organically produced food to have a sustainable competitive advantage over conventional food, their attributes must be relevant and significant to consumers (Hutchins \& Greenhalgh, 1997). In presentation and packaging, organically produced food should be clearly distinguished from conventional produce. Case studies of successful organically produced food products indicated that combining a persuasive message with excellent taste and attractive packaging was essential (Wright, 1997).

Further studies are needed if the conclusions of this preliminary study are applied to a larger sample and a wider target group. Included in future studies could be the role of babies and young children as a factor influencing the purchasing of organic foods. Contrasting evidence in this regard has been found in surveys conducted in the United States and Ireland (Lohr \& Semali, 2000:206; Davies et al, 1995).

It is important to know the characteristics and the beliefs of the consumers of organically produced products in order to target the specific group rather than 
the mass market. The beliefs of these consumers regarding organically produced food and organic farming have to be taken into account if marketing strategies are to succeed.

\section{REFERENCE LIST}

BASKER, D. 1988. Testing the perceived quality of food crops. Applied Agricultural Research 3(5):231232.

BEHARREL, B \& MACFIE, JH. 1991. Consumer attitudes to organic food. British Food Journal 93(2):25-30.

BENBROOK, C.1998. Organic farming: Facing choices at the crossroads. http://www.pmac.net.xroad.html. (Accessed 22 February 2001).

BUZBY, JC \& SKEES, JR. 1994. Consumers want reduced exposure to pesticides on food. Food Review 17(2):19-22.

DAVIES, A, TITTERINGTON, AJ \& COCHRANE, C. 1995. Who buys organic food? A profile of the purchasers of organic food in Northern Ireland. British Food Journal 97(10):17-23.

DE HAEN, $H$. 1999. Producing and marketing quality organic products: opportunities and challenges. $6^{\text {th }}$ IFOAM Trade Conference. http://www.fao.org/organcag/doc/IFOAM-.htm (Accessed 5 February 2001).

DU PLESSIS, F. (Ed) 1994. Buying behaviour. Strategic marketing applications. Johannesburg. International Thompson Publishing.

EHLERS, KM \& FOX, H. 1982. Food co-operative shoppers: nutrition knowledge, attitudes and concerns. Journal of the American Dietetic Association 80:160-162.

EKELUND, L. 1989. Vegetable consumption and consumer attitudes towards organically grown vegetables - the case of Sweden. Acta Horticulturae 259:163-172.

ENGEL, JF, BLACKWELL, RD \& MINIARD, PW. 1990. Consumer Behaviour. $6^{\text {th }}$ ed. Chicago. The Dryden Press.

FISHBEIN, M \& AJZEN, I. 1975. Beliefs, attitude, intention and behaviour: An introduction to theory and research. Reading. Addison-Wesley.

HACK, MD. 1993. Organically grown products: perception, preference and motives of Dutch consumers. Acta Horticultuae 340:247-253.

HARTMANN, P. 2001. Personal Interview, 19 March 2001. Woolworths Head Office, Cape Town

HAY, J. 1989. The consumer's perspective on organic foods. Agriculture Canada 10(4):45-50.

HUANG, CL .1996. Consumer preferences and attitudes towards organically grown produce. European Review of Agricultural Economics 23(3):331-342. HUTCHINS, RK \& GREENHALGH, LA. 1997. Organic confusion: sustaining competitive advantage. British Food Journal 99(9):336-338

JOLLY, DA, SCHUTZ, HGK, DIAZ-KNAUF, V \& JOHAL, J. 1989. Organic foods: consumer attitudes and use. Food Technology 43(110):60-66.

JOLLY, DA. 1991. Determinants of organic horticultural products consumption based on a sample of California Consumers. Acta Horticultrae 295:141-148.
JONES, P, CLARE-HILL, C, SHEARS, P \& HILLER, D. 2001. Retailing organic foods. British Food Journal 103(5):358-365(8).

LANE, S \& BRUHN, CM. 1992. Organic foods: their demand will remain low. Choices: The Magazine of Food, Farm and Resource Issues 7(1):3-4

LOHR, L \& SEMALI, A. 2000. Retailer decision making in organic produce marketing. In WJ Florkowski, SE Prussia \& RL Shewfelt (Eds). Integrated view of fruit and vegetable quality. Lancaster. PA:Technomic Publishing.

MAGNUSSON, MK, ARVOLA, A, HURSTI, UK, ÅBERG, L \& SJÖDÉN, P. 2001. Attitudes towards organic foods among Swedish consumers. British Food Journal 103(3) 209-227.

OTT, SL. 1990. Supermarket shoppers' pesticide concerns and willingness to purchase certified pesticide residue-free fresh produce. Agribusiness 6(6):593-602.

PETER, JP \& OLSON, JC. 1990. Consumer Behaviour and marketing strategy. $2^{\text {nd }}$ ed. Boston. Irwin. PETER, JP \& OLSON, JC. 1994. Understanding consumer behaviour. Burr Ridge. Irwin.

RODDY, G, COWAN, CA \& HUTCHINSON, G. 1996 Consumer attitudes and behaviour to organic foods in Ireland. Journal of International Consumer Marketing 9(2):41-63.

SAUNDERS, C. 1999. The potential for expansion of the organic industry in New Zealand: A contingent valuation of consumers WTP for organic produce. Discussion paper no. 77. Commerce Division, Lincoln University, Canterbury.

SCHIFFMAN, LG \& KANUK, LL. 1994. Consumer behaviour. $5^{\text {th }}$ ed. London. Prentice-Hall International.

SHETH, JN, MITTAL, B \& NEWMAN, BI. 1999. Customer behaviour. Consumer behaviour and beyond. London. The Dryden Press.

SLOAN, AE. 1999. Top ten trends to watch and work on for the millennium. Food Technology 53(8):40-60.

SWANSON, RB \& LEWIS, CE. 1993. Alaskan direct-market consumers: perceptions of organic produce. British Food Journal 96(4):21-25.

THOMPSON, GD. 1998. Consumer demand for organic foods: What we know and what we need to know. American Journal of Agricultural Economics (5):1113-1118.

THOMPSON, GD. 2000. International consumer demand for organic foods. HortTechnology 10(4):663-674.

TREGEAR, A, DENT, JB \& McGREGOR, MJ. 1994. The demand for organically-grown produce. British Food Journal 96(4):21-25.

VON ALVENSLEBEN, R. 1998. Ecological aspects of food demand: The case of organic food in Germany. AIR-CAT 4th Plenary Meeting. Health, Ecological and Safety Aspects in Food Choice 4(1):68-79. WANDEL, M \& BUGGE, A. 1997. Environmental concern in consumer evaluation of food quality. Food Quality and Preference 8(1):19-26.

WEAVER, RD, EVANS, DJ \& LULOFF, AE. 1992. Pesticide use in tomato production: consumer concerns and willingness-to-pay. Agribusiness 8(2):131142. 
WIER, M \& CALVERLEY, C. 2002. Market potential for organic foods in Europe. British Food Journal 104(1):45-62.

WILEY, N. 1996. South Africa and world-wide trends. Food Industries of South Africa (February):1417.

WILKINS JL \& HILLERS VN. 1994. Influences of pesticide residue and environmental concerns on organic food preference among food co-operative members and non-members in Washington State. Journal of Nutrition Education 26:26-33.

WILLIAMS, CM. 2002. Nutritional quality of organic food; shades of grey or shades of green. Proceedings of the Nutrition Society 61(1):19-24.

WILLIAMS, PR \& HAMMITT, JK. 2000. A comparison of organic and conventional fresh produce buyers in the Boston area. Risk Analysis 20(5):735-746.

WRIGHT, S. 1997. Exciting times for organic food. http://www.organic-consultancy.com/articlesifi.shtml (Accessed 30 January 2001). 